\title{
Modulation of ecdysal cyst and toxin dynamics of two Alexandrium (Dinophyceae) species under small-scale turbulence
}

\author{
L. Bolli ${ }^{1}$, G. Llaveria ${ }^{1}$, E. Garcés ${ }^{2}$, Ò. Guadayol ${ }^{1}$, K. van Lenning ${ }^{1}$, F. Peters ${ }^{1}$, and E. Berdalet ${ }^{1}$ \\ ${ }^{1}$ Institut de Ciències del Mar, CSIC, Passeig Marítim 37-49, 08003 Barcelona, Catalunya, Spain \\ ${ }^{2}$ IRTA, Ctra.de Poble Nou, Km 5.5, 43540 Sant Carles de la Ràpita Tarragona, Catalunya, Spain
}

Received: 6 March 2007 - Published in Biogeosciences Discuss.: 23 March 2007

Revised: 10 July 2007 - Accepted: 24 July 2007 - Published: 1 August 2007

\begin{abstract}
Some dinoflagellate species have shown different physiological responses to certain turbulent conditions. Here we investigate how two levels of turbulent kinetic energy dissipation rates $\left(\varepsilon=0.4\right.$ and $\left.27 \mathrm{~cm}^{2} \mathrm{~s}^{-3}\right)$ affect the PSP toxins and ecdysal cyst dynamics of two bloom forming species, Alexandrium minutum and A. catenella. The most striking responses were observed at the high $\varepsilon$ generated by an orbital shaker. In the cultures of the two species shaken for more than 4 days, the cellular GTX $(1+4)$ toxin contents were significantly lower than in the still control cultures. In A. minutum this trend was also observed in the $\mathrm{C}(1+2)$ toxin content. For the two species, inhibition of ecdysal cyst production occurred during the period of exposure of the cultures to stirring (4 or more days) at any time during their growth curve. Recovery of cyst abundances was always observed when turbulence stopped. When shaking persisted for more than 4 days, the net growth rate significantly decreased in $\mathrm{A}$. minutum (from $0.25 \pm 0.01 \mathrm{day}^{-1}$ to $0.19 \pm 0.02 \mathrm{day}^{-1}$ ) and the final cell numbers were lower (ca. 55.4\%) than in the still control cultures. In A. catenella, the net growth rate was not markedly modified by turbulence although under long exposure to shaking, the cultures entered earlier in the stationary phase and the final cell numbers were significantly lower (ca. 23\%) than in the control flasks.

The described responses were not observed in the experiments performed at the low turbulence intensities with an orbital grid system, where the population development was favoured. In those conditions, cells appeared to escape from the zone of the influence of the grids and concentrated in calmer thin layers either at the top or at the bottom of the containers.

This ecophysiological study provides new evidences about the sensitivity to high levels of small-scale turbulence by two life cycle related processes, toxin production and encystment, in dinoflagellates. This can contribute to the understanding of the dynamics of those organisms in nature.
\end{abstract}

Correspondence to: E. Berdalet

(berdalet@icm.csic.es)

\section{Introduction}

Many laboratory studies have investigated the sensitivity to small-scale turbulence by phytoplankton (reviews by Thomas et al., 1997; Peters and Marrasé, 2000; Berdalet and Estrada, 2005). Dinoflagellates appear as the group showing a diversity of particular responses to this, not well understood yet, environmental factor. The available data indicate that the direct effect of turbulence is species-specific and dependent on the experimental conditions (Berdalet and Estrada, 1993; Sullivan and Swift, 2003; Berdalet et al., 2007), although direct comparison between studies is not straightforward (Peters and Marrasé, 2000). Some studies have found positive (or indifferent) biological responses (Berdalet and Estrada, 1993; Sullivan and Swift, 2003; Havskum et al., 2005; Havskum and Hansen, 2006). Many others reported negative effects that, in general, point to the interference of small-scale turbulence with cell division and life cycle processes (including migration) (e.g., Berdalet, 1992; Pollingher and Zemel, 1981; Yeung and Wong, 2003).

This kind of experimental studies have been inspired on the observation that the occurrence of dinoflagellate red tides is favoured by relatively calm weather and water column stability coinciding with particular water circulation patterns (e.g., Wyatt and Horwood, 1973; Margalef et al., 1979; Pollingher and Zemel, 1981; Berman and Shteiman, 1998) although they also develop in frontal zones (Estrada and Blasco, 1979; Smayda and Reynolds, 2001). Given the ecological and socioeconomic importance of dinoflagellate blooms, it is important to study the different factors that can modulate their dynamics. Although the laboratory approaches will never mimic nature, they can help to ascertain the underlying mechanisms of cell responses to particular factors that cannot be separated from the rest of forcings in the field.

The aim of the present study was to increase the information on the sensitivity to small-scale turbulence of two redtide forming dinoflagellates, Alexandrium catenella (Whedon and Kofoid) Balech and Alexandrium minutum Halim,

Published by Copernicus Publications on behalf of the European Geosciences Union. 
with special emphasis on the modulation of toxin and cyst production dynamics. The two organisms are reported to bloom in coastal areas (e.g. Halim, 1960; Delgado, 1990; Honsell et al., 1995; Hallegraef et al., 1998; Vila et al., 2001a, b). A previous study combining both field and laboratory work (Sullivan et al., 2003), hypothesized that A. catenella actively concentrated at depths with low turbulence and shear. In another experimental study (Berdalet et al., 2007), high turbulence intensity decreased the growth of A. minutum and interfered somehow with cyst production, although a clear conclusion was not drawn and the authors mentioned the need of further tests. Dinoflagellates have complex life cycles that include alternation of resting stages (cysts senso lato) and vegetative cells, with benthic or planktonic phases, respectively (e.g. Wyatt and Jenkinson, 1997; Garcés et al., 2002). In turn, cysts can be sexually formed from the fusion of haploid gametes (producing a diploid planozygote that subsequently undergoes encystment) or asexually from ecdysis of a vegetative cell (loss of flagella and cell wall). In general, sexually and asexually formed cysts are considered, respectively, resting and temporary cysts. Different factors can trigger encystment and excystment after latency, but the mechanisms involved and the role of cysts in the dynamics of blooms in nature are not well understood. Both, A. minutum and A. catenella are heterothallic species (Yoshimadzu, 1984; Figueroa et al., 2007) and are reported to produce ecdysal cysts in clonal strains. Further, exposure to small-scale turbulence has been reported to cause poor sexual encystment in A. tamarense (Anderson and Lindquist, 1985), inhibition of sexual cyst production in Akashiwo sanguinea (Tynan, 1993, as indicated in Thomas et al., 1997) and in Scrippsiella lachrymosa (Smith and Persson, 2005), and increase of cellular toxin content in A. fundyense (Juhl et al., 2001).

In this study we chose two experimental setups that were used previously in other studies performed in our laboratory with A. minutum and other species (Berdalet, 1992; Berdalet and Estrada, 1993; Havskum et al., 2005; Berdalet et al., 2007) with the aim of allowing direct comparison between data. High turbulence was produced in 4-1 sphaerical flasks containing 31 of medium agitated by an orbital shaker. This setup and shaking intensities guaranteed turbulent conditions in the whole container and provided the large volumes needed for the appropriate sampling of biological parameters (in particular, toxin concentration) while at the same time allowed direct comparison to previous experiments. A lower level of turbulence intensity was achieved with a verticallyoscillating grid system and 2-1 cylindric vessels.

\section{Materials and methods}

The clonal strain of Alexandrium minutum (strain IEO AL1V) was provided by the Vigo Oceanographic Center (Spain) and that of Alexandrium catenella (isolated by M. Delgado from the Tarragona Harbor, NW Mediterranean) belongs to the ICM culture collection. Non-axenic stock and experimental unialgal cultures were maintained in a temperature controlled room under identical temperature $\left(20^{\circ} \mathrm{C} \pm 1^{\circ} \mathrm{C}\right)$, irradiance $\left(120 \mu\right.$ mol photon $\mathrm{m}^{-2} \mathrm{~s}^{-1}$, 12:12 $\mathrm{h} \mathrm{LD} \mathrm{cycle,} \mathrm{light} \mathrm{period} \mathrm{starting} \mathrm{at} \mathrm{08:00} \mathrm{a.m.)} \mathrm{and} \mathrm{cul-}$ ture media ( $\mathrm{f} / 2$-enriched seawater without silicate addition, Guillard, 1975; seawater of salinity 38 obtained from Blanes Bay -NW Mediterranean-, $1 \mathrm{~km}$ offshore at a $5 \mathrm{~m}$ depth). Turbulence was generated with either an orbital shaker or a vertically oscillating grid system. The orbital shaker was operated at $120 \mathrm{rpm}$ and a displacement of $30 \mathrm{~mm}$. We used 4-1 spherical (Florence) flasks (containing 31 culture medium). An average $\varepsilon$ of $27 \mathrm{~cm}^{2} \mathrm{~s}^{-3}\left(2.7 \times 10^{-3} \mathrm{Watt} \mathrm{kg}^{-1}\right)$ was calculated from the equation $\log _{10} \varepsilon-8.667+5.05 \mathrm{~F}$, where $\mathrm{F}$ is frequency in $\mathrm{Hz}$. This equation was derived from data acquired with a side-looking acoustic Doppler velocimeter (NDVlab, Nortek AS, Rud, Norway) for a range of oscillating frequencies and positions within the flask (Guadayol et al., $2007^{1}$ ). The power spectra from the velocity time series were analysed to calculate $\varepsilon$ using the linear regression method developed by Stiansen and Sundby (2001). The oscillating grids device, as described by Dolan et al. (2003), was designed by one of us (F. Peters). The grids were made of stainless steel coated with a plastic polyamide, had a diameter of $11.9 \mathrm{~cm}$, a $0.38 \mathrm{~cm}$ bar thickness and a mesh size of $1.42 \mathrm{~cm}$. We used 2-1 cylindrical Plexiglas containers, an oscillating frequency of $9.1 \mathrm{rpm}$ and a stroke of 10 to $11 \mathrm{~cm}$. An average $\varepsilon$ of $0.4 \mathrm{~cm}^{2} \mathrm{~s}^{-3}\left(4 \times 10^{-5} \mathrm{Watt} \mathrm{kg}^{-1}\right)$ was calculated following Peters and Gross (1994), considering a drag coefficient of 0.7 for the grid.

Experimental vessels were inoculated after several transfers of exponentially growing stock cultures to new media. The initial cell concentration was around 400 cells ml$^{-1}$ for A. minutum and 65 cells ml $^{-1}$ for A. catenella. The cultures were allowed to reach exponential phase before turbulence was started. Turbulence was applied during the exponential phase (Exponential), the stationary phase (Stationary) or during both phases (Always) of the growth curve (Table 1). In each experiment, two flasks remained under still conditions throughout the entire experiment (Control). All treatments were done in duplicate. The response of A. catenella to the turbulence generated by the orbital shaker was studied in two experiments (Table 1). In the first one, 4 treatments were applied and only samples for microscopic observations were obtained. In the second one, with only two treatments (Control and Always), we also sampled for toxin analyses. Samples for microscopic cell observations and toxin analyses were taken at noon (12:00 p.m.). Because cells showed

\footnotetext{
${ }^{1}$ Guadayol, Ò., Peters, F., Stiansen, J. E., Marrasé, C., and Lohrmann, A: Evaluation of oscillating grids and orbital shakers as means to generate isotropic and homogeneous small scale turbulence in laboratory enclosures commonly used in plankton studies, in review, 2007.
} 
Table 1. Net exponential growth rates $\left(\mu\right.$ day $\left.^{-1}\right)$ and final biomass yield (cells $\mathrm{ml}^{-1}$ ) in each treatment of the 5 experiments performed in this study. " $n$ " indicates the number of replicates considered for every calculation. For the estimations of $\mu$ we indicate the duration of the exponential growth phase (Expon. duration, days) considered for the calculations of the regression line and its associated standard error and adjusted multiple $r^{2}$; " $p$ " indicates the degree of significance of the heterogeneity of the slopes tests (analysis of covariance) run to compare the growth rate during the shaking period with that of the Control (unshaken) ones. A comparison between the final yield obtained at the end of each experiment under turbulent conditions and the still ones is indicated as the T/S\% percentage.

\begin{tabular}{|c|c|c|c|c|c|c|c|c|c|c|c|c|}
\hline \multirow[b]{2}{*}{ Experiment } & \multirow[b]{2}{*}{ Treatment } & \multirow[b]{2}{*}{$\begin{array}{c}\text { Turbulent } \\
\text { duration } \\
\text { (days) }\end{array}$} & \multicolumn{6}{|c|}{ Effect on growth rate } & \multicolumn{4}{|c|}{ Effect on final cell numbers } \\
\hline & & & $\mathrm{n}$ & $\begin{array}{l}\text { Expon. } \\
\text { duration } \\
\text { (days) }\end{array}$ & $\begin{array}{c}\mu \\
\left(\mathrm{day}^{-1}\right)\end{array}$ & err & $r^{2}$ & $\mathrm{p}$ & $\mathrm{n}$ & cells $\mathrm{ml}^{-1}$ & err & $\% \mathrm{~T} / \mathrm{S}$ \\
\hline \multirow{4}{*}{$\begin{array}{l}\text { A. minutum } \\
\text { Orbital } \\
27 \mathrm{~cm}^{2} \mathrm{~s}^{-3}\end{array}$} & Control & none & 4 & $5-13$ & 0.25 & 0.01 & 0.983 & \multirow{3}{*}{0.704} & 2 & 8458 & 825 & \\
\hline & Exponential & $5-9$ & 2 & $5-13$ & 0.23 & 0.01 & 0.988 & & 2 & 8142 & 258 & 96.3 \\
\hline & Stationary & $11-15$ & & & & & & & 2 & 7317 & 333 & 86.5 \\
\hline & Always & $5-21$ & 2 & $5-13$ & 0.19 & 0.02 & 0.945 & 0.000 & 2 & 4690 & 130 & 55.4 \\
\hline \multirow{2}{*}{$\begin{array}{l}\text { A. minutum. } \\
\text { Grids } \\
0.4 \mathrm{~cm}^{2} \mathrm{~s}^{-3}\end{array}$} & Control & none & 2 & $0-10$ & 0.26 & 0.01 & 0.994 & \multirow[b]{2}{*}{0.077} & 2 & 7725 & 158 & \\
\hline & Always & $4-14$ & 2 & $0-10$ & 0.28 & 0.01 & 0.986 & & 2 & 9813 & 263 & 127.0 \\
\hline \multirow{4}{*}{$\begin{array}{l}\text { A. catenella. } \\
\text { Orbital shaker I } \\
27 \mathrm{~cm}^{2} \mathrm{~s}^{-3}\end{array}$} & Control & none & 4 & $5-13$ & 0.21 & 0.01 & 0.934 & \multirow{3}{*}{0.375} & 2 & 2228 & 597 & \\
\hline & Exponential & $4-8$ & 2 & 5-9 & 0.21 & 0.01 & 0.899 & & 2 & 2066 & 161 & 92.7 \\
\hline & Stationary & $12-16$ & & & & & & & 2 & 2047 & 522 & 91.9 \\
\hline & Always & $4-21$ & 2 & 5-9 & 0.23 & 0.06 & 0.620 & 0.392 & 2 & 549 & 49 & 24.7 \\
\hline \multirow{2}{*}{$\begin{array}{l}\text { A. catenella. } \\
\text { Orbital shaker II } \\
27 \mathrm{~cm}^{2} \mathrm{~s}^{-3}\end{array}$} & Control & none & 2 & $0-10$ & 0.23 & 0.02 & 0.954 & \multirow[b]{2}{*}{0.105} & 2 & 3425 & 700 & \\
\hline & Always & $4-21$ & 2 & $0-10$ & 0.20 & 0.01 & 0.959 & & 2 & 739 & 61 & 21.6 \\
\hline \multirow{4}{*}{$\begin{array}{l}\text { A. catenella. } \\
\text { Grids } \\
0.4 \mathrm{~cm}^{2} \mathrm{~s}^{-3}\end{array}$} & Control & none & 4 & $0-11$ & 0.31 & 0.01 & 0.970 & \multirow{3}{*}{0.096} & 2 & 4820 & 330 & \\
\hline & Exponential & $3-7$ & 2 & $0-11$ & 0.33 & 0.01 & 0.983 & & 2 & 5016 & 4 & 104.1 \\
\hline & Stationary & $11-15$ & & & & & & & 2 & 5625 & 1350 & 116.7 \\
\hline & Always & $3-20$ & 2 & $0-11$ & 0.35 & 0.01 & 0.991 & 0.001 & 2 & 7233 & 133 & 150.1 \\
\hline
\end{tabular}

heterogeneous distributions in the flasks it was necessary to carefully mix them in order to obtain representative samples. The sphaerical still flasks were gently swirled and all the 2-1 cylinders (shaken or not) were turned upside down 10 times.

Cell abundances were estimated using a Sedgewick-Rafter or a sedimentation chamber (Utermöhl, 1958), depending on the cell density of the sample, after fixation with Lugol's iodine solution. Net exponential growth rates, $\mu\left(\right.$ day $\left.^{-1}\right)$, as defined by Guillard (1973), were calculated as the slope of the regression line of $\ln (\mathrm{N})$ versus time $(\mathrm{t})$, where $\mathrm{N}$ was the estimated cell concentration. Cyst identification was based both on the external morphology and subsequent staining of a subsample with Calcofluor White M2R (Fritz and Triemer, 1985). For paralytic shellfish toxin (PSP) analysis, 100 to $300 \mathrm{ml}$ of culture were required for detection. Due to this required sample volume, sampling could only be done at the beginning (from the mother culture) and at the end in the 2-1 vessels of the vertically oscillating grids setup. In those experiments sampling could only be done at the beginning (from the mother culture) and at the end in the 2-1 vessels of the vertically oscillating grids setup. The samples were concentrated by vacuum filtration $(-25 \mathrm{kpa})$ onto $25 \mathrm{~mm}$ GF/F filters (Whatman, Kent, UK). Filters were subsequently blotted on filtration paper until no humidity was observed in the latter (Latasa et al., 2001), wrapped in aluminium foil and stored frozen $\left(-25^{\circ} \mathrm{C}\right)$ until extraction. The filters were extracted in $2.0 \mathrm{ml} 0.05 \mathrm{M}$ analytical-grade acetic acid, using an ice-cooled cell-homogenizer (Edmund-Bühler Vibrogen, Tübingen, Germany). Extracts were subsequently centrifuged $\left(2355 \mathrm{~g}, 15 \mathrm{~min}\right.$ at $\left.5^{\circ} \mathrm{C}\right)$ to remove cell debris and filter fragments. Particle-free aliquots $(1.0 \mathrm{ml})$ were transferred to amber injection vials and stored cold $\left(5^{\circ} \mathrm{C}\right)$ in the HPLC auto-sampler until injection. Extracts of toxins were analyzed with the HPLC procedures described by Oshima (1995), based on post-column oxidation with periodic acid and fluorescence detection. Toxins were separated on an Agilent Technologies Zorbax-SB C8 $(250 \times 4.6 \mathrm{~mm}$ i.d.) column fitted with a BetaBasic C8 Javelin precolumn. The HPLC equipment (Thermo Separation Products, San José, CA, USA) was tested and calibrated with toxin standards obtained from the NRC (Hallifax, Canada), including GTX1\&4-b, GTX2\&3-b, STX-d, dcSTX, STXdiAc and Neo-b. Due to the lack of standards for N-sulfocarbamoyl11-hydroxysulfate toxins ( $\mathrm{C} 1$ to $\mathrm{C} 4$ ) these compounds were converted to their carbomate analogues with a hydrolization step $(1 \mathrm{ml}$ acetic acid extract plus $1 \mathrm{ml} \mathrm{HCl} 0.4 \mathrm{~N}$ and boiled at $100^{\circ} \mathrm{C}$ for $15 \mathrm{~min}$ ), which were subsequently quantified during a second HPLC run.

Comparison of treatments over time for the different parameters was done using the non-parametric Kruskal-Wallis test (Motulsky, 2003). Growth rates were compared by testing for the heterogeneity of the slopes (analysis of covariance). Statistical analyses were conducted with Systat 5.1.2 for MacIntosh.

\section{Results}

Table 1 summarizes the results of net growth rate and final cell numbers estimated in the different treatments for the 5 experiments. Note that the estimation of growth rates under still conditions include 4 replicates, corresponding to the 2 Control flasks and to the 2 vessels that were kept unshaken 

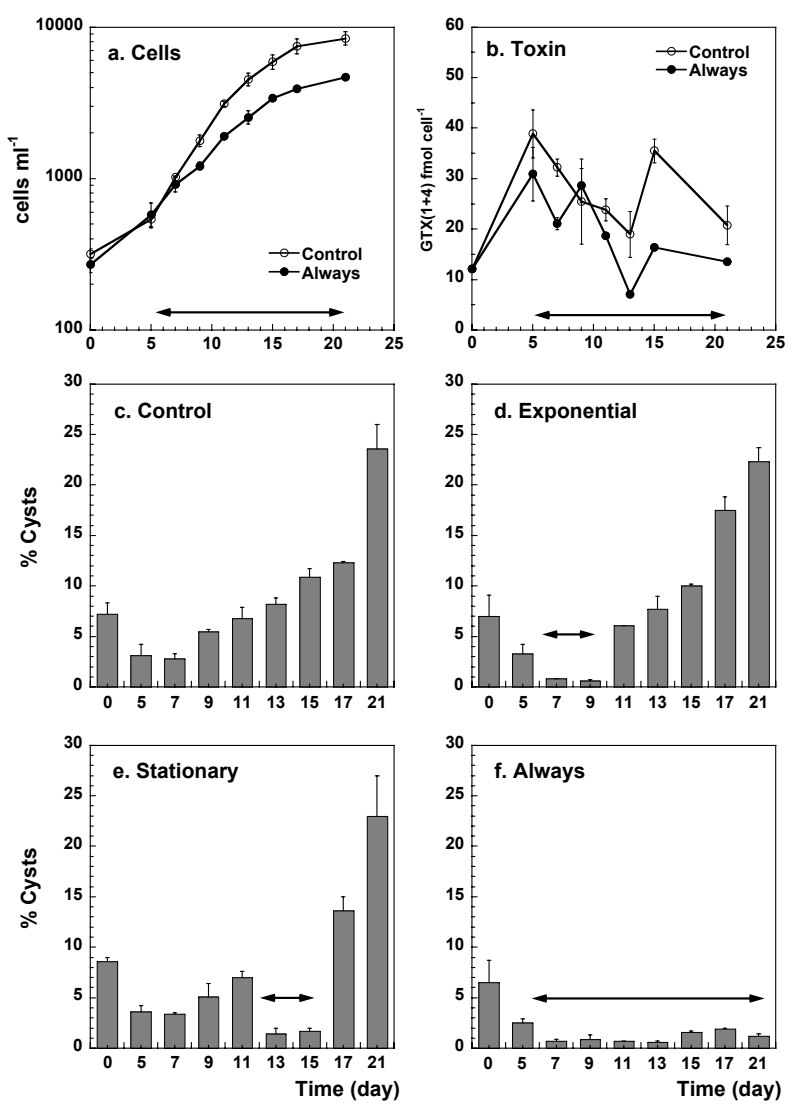

Fig. 1. (a): Temporal changes in A. minutum cell numbers in the unshaken Control (white symbols) and the turbulence Always treatment (black symbols). The turbulence treatment was done with an orbital shaker between days 5 to 21 (Table 1). The temporal changes of the other two shaken treatments (Exponential and Stationary, Table 1) were not significantly different from those of the Control ones and are not shown for clarity. (b): Temporal changes in the GTX $(1+4)$ toxin content in the Control and the Always treatments. (c) to (f): Temporal changes in ecdysal cysts abundances (expressed as percentage of the total cell numbers) in each treatment of the experiment. Vertical bars indicate the standard error of the mean, and the shaken period of each treatment is marked by the double arrow horizontal line.

during the exponential period and subsequently stirred during the stationary one (i.e. Stationary treatment). Table 2 contains the statistics of the comparison of the toxin content and the percentage of cyst abundances between the different shaken treatments in each experiment with their corresponding Control.

Experiments with the orbital shaker

In general, exposure to the high $\varepsilon$ intensities generated by the orbital shaker did not significantly modify the exponential growth rate of the shaken treatments compared to that of the unshaken ones (Table 1, Figs. 1a and 2a). Only the A. minu-
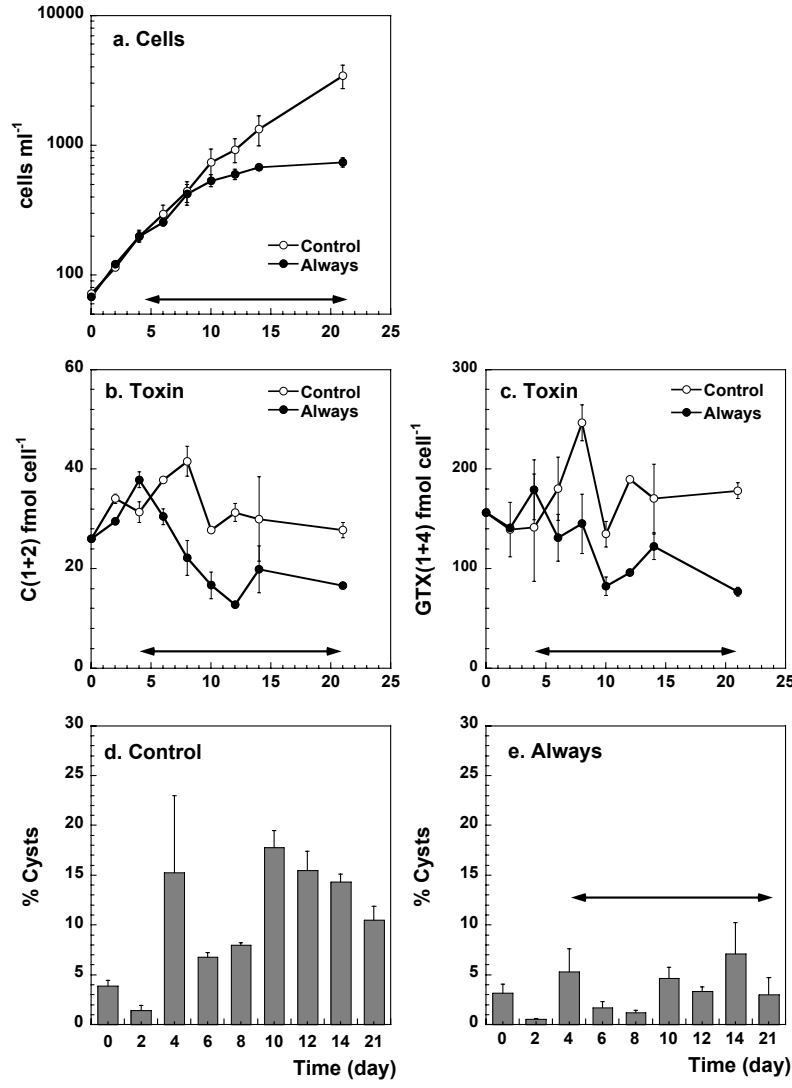

Fig. 2. Temporal changes in the cell numbers (a), the toxin content (b and c) and the ecdysal cyst abundances in the second experiment performed with A. catenella in the orbital shaker with only two treatments (Control and Always, Table 1). Vertical bars indicate the standard error of the mean, and the shaken period of each treatment is marked by the double arrow horizontal line.

tum cultures exposed to turbulence for more than 4 days ( $\mathrm{Al}$ ways treatment, Table 1, Fig. 1a) grew significantly slower $\left(0.19 \pm 0.02 \mathrm{day}^{-1}\right)$ than their Control $\left(0.25 \pm 0.01 \mathrm{day}^{-1}\right)$. The two species showed slightly lower final cell numbers when shaken for 4 days either during the exponential or the stationary phase, namely between $86.5 \%$ and $96.3 \%$ of the abundances obtained in the Control cultures (Table 1). The lowest final cell concentrations were estimated in the Always treatments, $55.4 \%$ in the A. minutum experiment (Fig. 1a) and $24.7 \%$ or $21.6 \%$ in the ones with A. catenella (Fig. 2a).

The toxin content of both, the A. minutum and the A. catenella strains, consisted mainly of the isomer pair GTX1 and GTX4, plus minor amounts of $\mathrm{C} 1$ and $\mathrm{C} 2$. At the beginning of the experiment with $A$. minutum its $\mathrm{C}(1+2)$ and GTX $(1+4)$ contents were, respectively, $0.46 \mathrm{fmol} \mathrm{cell}^{-1}$ and $12 \mathrm{fmol} \mathrm{cell}^{-1}$. Those values peaked on day 5 and decreased afterwards with some oscillation until the end of the experiment in all treatments. There were not significant differences (Table 2) between the contents of the two toxin estimated in 
Table 2. Statistics values of the comparison between the toxin content and the cyst abundances of each turbulent treatment with its corresponding still Control, for each of the 5 experiments performed in this study. U: Mann-Whitney non-parametric analysis of variance; p: degree of significance; $n$ : number of data included in the statistical test. The tests compared the data during the shaking period of each treatment and the corresponding days of the Control. However, in the experiments with the oscillating grids, the comparison of the toxin contents was done only on the last day of each experiment.

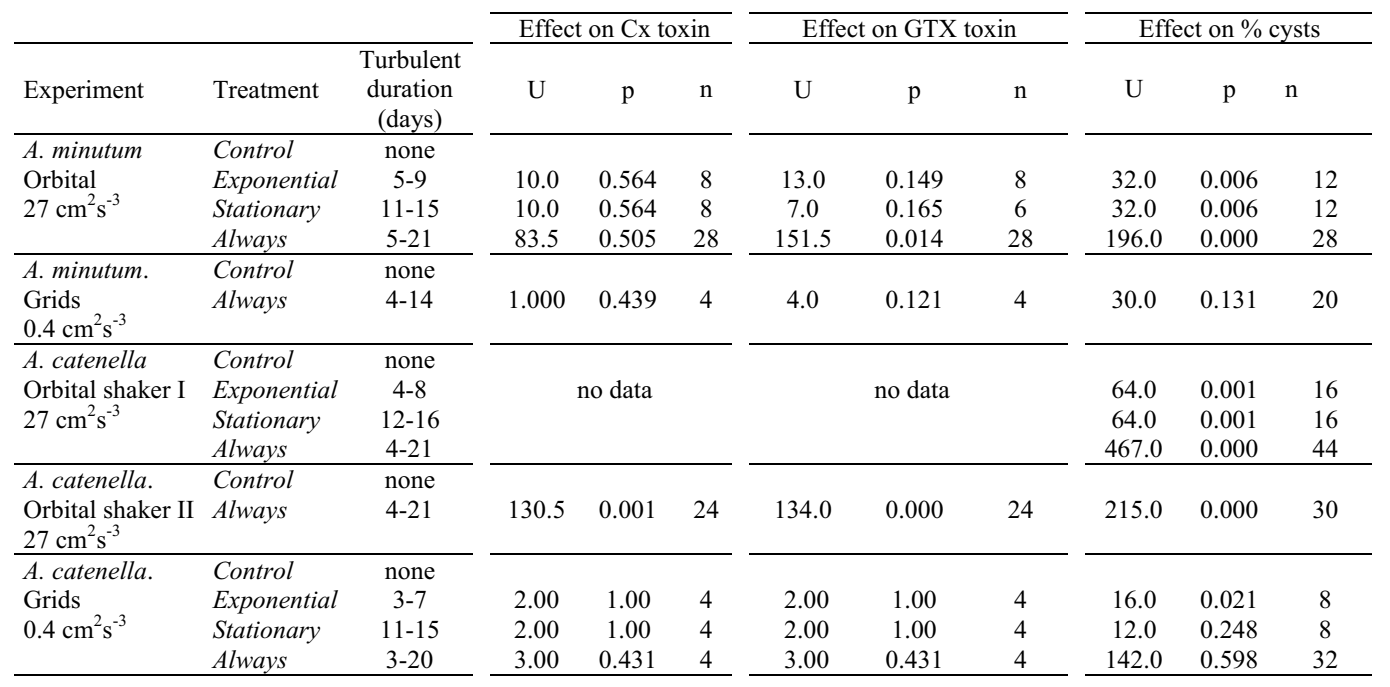

the Control and in the flasks shaken during the exponential or the stationary phase, nor in the $\mathrm{C}(1+2)$ levels estimated in the Always treatments. Only the GTX content in the Always flasks was significantly higher $\left(19.5 \pm 2.2\right.$ fmolcell $^{-1} ; n=14$; mean \pm SEM) than in the Control $\left(26.9 \pm 2.4 \mathrm{fmol} \mathrm{cell}^{-1}\right.$, $\mathrm{n}=14$; Fig. 1b, Table 2). Overall, the range of the two toxins measured in A. minutum, considering the whole data set was $0.9 \pm 0.05 \mathrm{fmol} \mathrm{cell}^{-1}$ and $21.3 \pm 1.3 \mathrm{fmol} \mathrm{cell}^{-1}(\mathrm{n}=57)$.

The toxin levels of $A$. catenella were several times higher than that of A. minutum (Figs. $2 \mathrm{~b}$ and c). At the beginning of the experiment the $\mathrm{C}(1+2)$ and GTX $(1+4)$ contents were, respectively, $26 \mathrm{fmol} \mathrm{cell}^{-1}$ and $156 \mathrm{fmol} \mathrm{cell}^{-1}$. As illustrated in Figs. $2 b$ and c, the levels of the two toxins in this species were significantly lower (Table 2 ) in the Always treatments $\left(109.2 \pm 9.2 \mathrm{fmol} \mathrm{cell}^{-1} \mathrm{GTX}(1+4)\right.$ and $19.8 \pm 1.9 \mathrm{fmol} \mathrm{cell}^{-1}$ $\mathrm{C}(1+2), \mathrm{n}=12)$ than in the Control $\left(169.7 \pm 9.2 \mathrm{fmol} \mathrm{cell}^{-1}\right.$ $\operatorname{GTX}(1+4)$ and $\left.32.6 \pm 1.2 \mathrm{fmol} \mathrm{cell}^{-1} \mathrm{C}(1+2), \mathrm{n}=21\right)$.

Cyst abundances (expressed as \% of the total cell numbers) tended to progressively increase in the A. minutum Control cultures from the exponential to the stationary phase (Fig. 1c). A sudden decrease in the cyst numbers were observed when the cells were shaken for 4 days either during the exponential (Fig. 1d) or stationary (Fig. 1e) phases. In those shaking periods, the percentage of ecdysal cysts were significantly lower compared to the corresponding days (days 5-9 and 11-15, respectively) of the experiment in the Control (Table 2). Immediate restoration of cyst abundances occurred at the cessation of shaking in the two treatments. In the Always flasks, significantly lower cyst proportions remained during the whole agitation period (Fig. 1f, Table 2,
$\mathrm{U}=196.0, \mathrm{p}=0.0001$, compared to the $\%$ of cysts from days 6 to 21 in the Control).

The same general trend was observed in the two experiments with A. catenella. In the first experiment with this species, the cyst numbers in the Control flasks contributed $15.3 \% \pm 3.1(n=32)$ of the total cell numbers along the whole experiment. During the shaking periods, the percentage of cysts dropped significantly (Table 2) with values around $1.1 \% \pm 0.3(\mathrm{n}=8)$ in the Exponential, $7.8 \% \pm 1.6(\mathrm{n}=8)$ in the Stationary and $1.6 \% \pm 0.3(\mathrm{n}=26)$ in the Always treatments. A similar figure was found in the second experiment (Figs. 2d and e, Table 2), concerning the Always and the Control cultures.

Experiments with the vertically oscillating grids

Exposure to the low turbulence intensity generated by the vertically oscillating grids favoured the population development of the two species (Figs. 3a and b, Table 1). In the A. catenella experiment both, the net growth rate and the final cell numbers increased with the duration of the shaking period (Table 2). After 2 days of shaking, visual inspection of the containers seemed to point towards an accumulation of cells at the top and the bottom of the containers, suggesting that dinoflagellates could have possibly escaped turbulence since the grid did not reach the ends of the cylinders. At the bottom, the aggregation areas conformed to the geometry of the grids, i.e. with cells concentrated forming empty squares. Aggregates homogeneously distributed at the bottom of the cylinders were also observed in the still treatments, when they entered the stationary phase. 

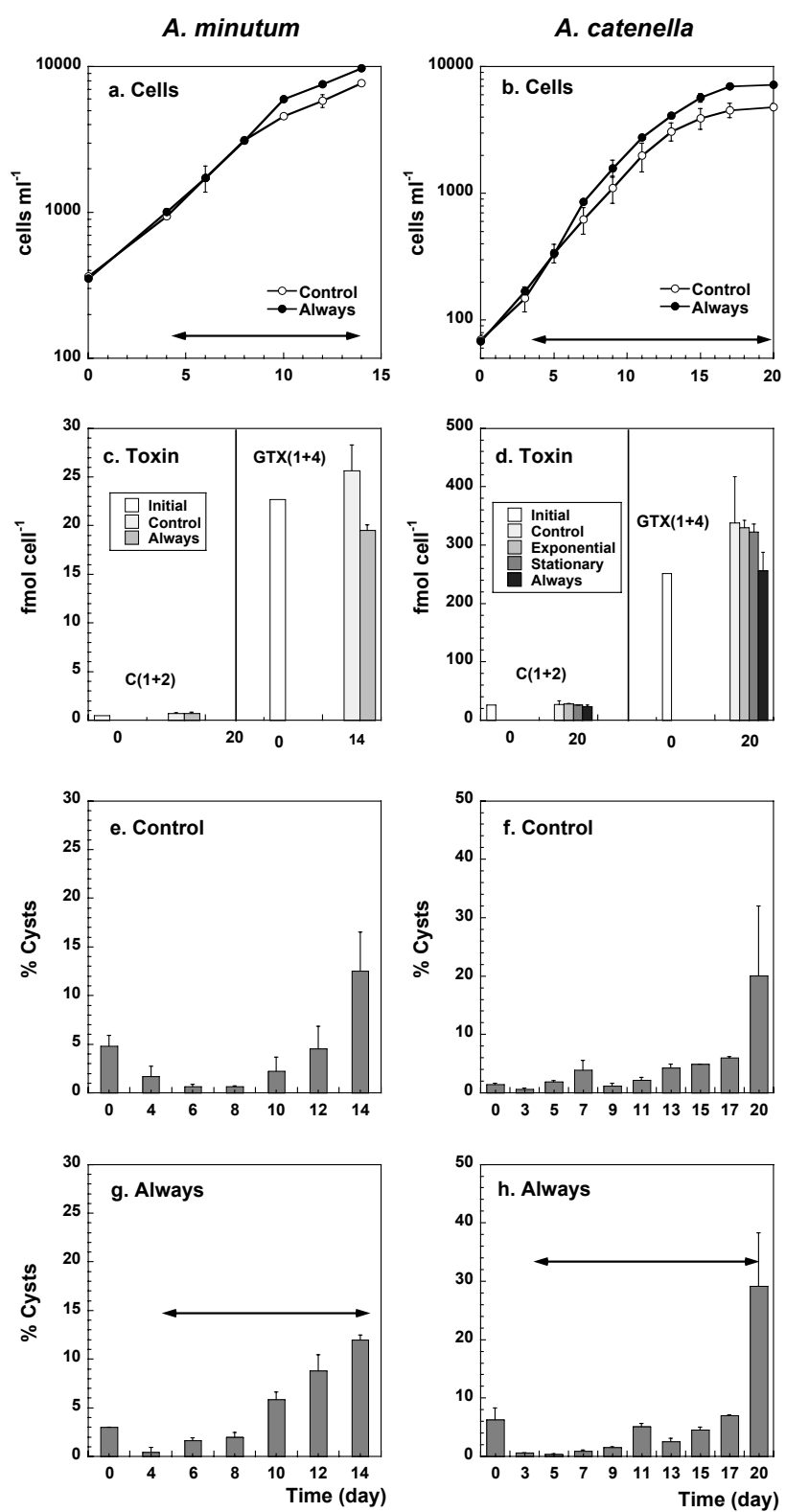

Fig. 3. Temporal changes in the different parameters estimated in the experiments performed with the vertically oscillating grids in A. minutum (a, c, e and $\mathbf{g}$ ) and $A$. catenella $(\mathbf{b}, \mathbf{d}, \mathbf{f}$ and $\mathbf{h})$. For simplicity, only the cell numbers and \% cyst abundances of the Control and the Always treatments of the A. catenella experiment are shown; the description of the Exponential and Stationary cultures can be found in the text and in Table 2. (a) and (b) correspond to the temporal changes in cell numbers. (c) and (d) show the cell concentration of the $\mathrm{C}(1+2)$ and the GTX $(1+4)$ on the first day and at the end of each experiment. (e) and (f) display the changes in the cyst abundances of the still Control and (g) and (h) correspond to the Always treatments. Vertical bars indicate the standard error of the mean, and the shaken period of each treatment is marked by the double arrow horizontal line.
The experiments with grids showed inconclusive results concerning the cellular content of both GTX(1+4) and $\mathrm{C}(1+2)$, since samples could only be taken on the first and the last day (Figs. 3c and d). There were no significant differences between each shaken treatment and the unshaken ones on the last day of each experiment (Table 2).

The dynamics of the cyst abundances was similar between the different treatments (Figs. 3e to h). In the unshaken Control (Figs. 3e and $\mathrm{f}$ ) they remained below the $10 \%$ or the $5 \%$ in A. catenella and A. minutum, respectively, and tended to increase (up to the $30 \%$ or the $12 \%$, respectively) when the cultures entered the stationary phase. In general, turbulence did not significantly modify this trend (Table 2), except in the Exponential treatment of the A. catenella experiment, where the cyst abundances were significantly lower than in the Control treatment during the shaking period (days 4-7, Table 2). When turbulence stopped, cyst abundances increased and reached similar levels than in the Control.

\section{Discussion}

The experiments using the vertically oscillating grids were performed at $\varepsilon$ intensities (ca. $0.4 \mathrm{~cm}^{2} \mathrm{~s}^{-3}$ ) considered to naturally occur in the upper $10 \mathrm{~m}$ of the ocean under storm events (MacKenzie and Leggett, 1993; Kiørboe and Saiz, 1995; Petersen et al., 1998). The much higher $\varepsilon$ generated in the orbital shaker $\left(27 \mathrm{~cm}^{2} \mathrm{~s}^{-3}\right)$ would be even higher than those associated with intense wind conditions $\left(>20 \mathrm{~m} \mathrm{~s}^{-1}\right.$, Granata and Dickey, 1991; MacKenzie and Leggett, 1993; Kiørboe and Saiz, 1995), and would only be experienced by cells in the surf zone or rocky intertidal. Our experimental values of $\varepsilon$ were large, both in intensity and persistence, compared to Mediterranean turbulence events (Guadayol and Peters, 2006), although 4-day sustained events of $0.4 \mathrm{~cm}^{2} \mathrm{~s}^{-3}$ do occur sometimes. Thus we chose this duration for some experimental conditions during either the exponential or the stationary phase of the growth curve. The physiological responses at this time scale also served to compare with the trends under still control conditions and under longer periods of exposure to shaking (16-17 days). The turbulence generated is also qualitatively different for each laboratory setup as it is different from field turbulence (Peters and Redondo, 1997). With their limitations, but also with their particular advantages, these experimental conditions may help to ascertain the underlying mechanisms of cell adaptations. The following discussion is developed within a physiological context with no aim to directly extrapolate to nature.

Both the net growth rates and the final cell numbers of the two species increased when mixed at the lowest $\varepsilon$ intensity with the vertically oscillating grids for 4 or more days. With the same setup and similar experimental design and turbulence conditions, different species-specific responses have been observed: while the net growth rates of Oxyrrhis marina (Havskum, 2003) and of Ceratium tripos (Havskum et 
al., 2005) decreased, the one of Fragilidium subglobosum was not affected (Havskum et al., 2005) and that of Heterocapsa triquetra was favoured (Havskum and Hansen, 2006). In this last study, those authors suggested that turbulence facilitated gas exchange and avoided excessive $\mathrm{pH}$ increase in the experimental vessels allowing higher cell numbers than in the still flasks. This mechanism could have operated also in our experiments, where the two species concentrated either at the top or the bottom of the cylinders where the grids did not pass. There, cells could proceed with their life cycle relatively undisturbed, including cyst formation (see below). Given that dinoflagellates managed to escape from the mixed zone, we cannot conclude that low turbulence stimulated dinoflagellate growth nor suggest any hypothesis for natural conditions. The noticeable result here is that the two species were likely sensitive to the tested turbulence intensity, as they swam away from it and chose preferentially calm zones.

In contrast, it is not possible to escape from the turbulence generated by the orbital shaker. However, the decrease in the net growth rate in A. minutum and the lowest final numbers in the two species were only observed when shaking lasted for more than 4 days. Those trends were similar to those described in previous studies with A. minutum under similar experimental conditions (Berdalet et al., 2007) and with A. catenella conducted at $\varepsilon$ of ca. $10^{-4}$ and ca. $1 \mathrm{~cm}^{2} \mathrm{~s}^{-3}$ generated by horizontal rods oscillating in 20-1 tanks (Sullivan and Swift, 2003). In the two studies, shaking lasted for 1-2 weeks. Overall the data indicate that even the highest intensities and persistence levels of turbulent conditions that can be generated naturally, would have no lethal effects on our tested dinoflagellates.

The most immediate response was the decay of ecdysal cyst abundances when the cultures were intensively shaken for only 4 days, and the subsequent and fast recovery once turbulence stopped. The persistence of significantly lower cyst numbers in the cultures shaken for more than 4 days confirmed this trend. Those results agree with previous studies (Anderson and Lindquist, 1985; Smith and Persson, 2004, 2005). Magnetic stirring for up to one month of Scrippsiella lachrymosa and Alexandrium fundyense cultures prevented their sexual encystment. Once stirring was stopped, dinoflagellates resumed their regular mating behaviour. Turbulence would have denied them the stability for this process, without alteration of their physiological capacity to encyst. Smith and Persson (2004) suggested that sexual cyst formation would require a surface or boundary layer to facilitate the gamete meeting and initiation of mating. Subsequently, during the cyst formation, the cell wall gets stickier and zygotes sink to the bottom (of the container) or to the sediment. Although we are dealing here with asexual ecdysal cysts of $A$. minutum and A. catenella, a similar mechanism of interference by turbulence could also be acting. In nature, a certain degree of stability is usually associated with the outbreak, development and maintenance of dinoflagellate blooms (e.g. Margalef et al., 1979; Berman and Shteiman, 1998; Smayda and
Reynolds, 2001) and dinoflagellates selectively accumulate in thin layers (e.g. A. catenella as observed by Sullivan et al., 2003). In our present study, the inhibition of the net population development observed in A. catenella and A. minutum during the long exposure to high turbulence intensities could be a combination of a direct alteration of the vegetative cell division and the interference with the ecdysal cyst formation. Our observation also indicates that high turbulence was not a factor that induced the asexual encystment of these two species. On the contrary, ecdysal cysts must be an essential phase of the life cycles of these organisms playing a major role in population dynamics of certain dinoflagellates and requiring stability of the water column to proceed.

Regarding toxins, the results in the two experiments with the orbital shaker are opposite to those for A. fundyense that increased its cellular toxin content when exposed to $0.1 \mathrm{~cm}^{2} \mathrm{~s}^{-3}$ in Couette devices (Juhl et al., 2001). Likely, differences in the physiological state of the cultures and/or the experimental setup and design used in each study have conditioned these opposite responses. In consequence, it is too soon to draw general conclusions and the question about the possible effect of turbulence on toxin production continues to be an open one.

Certainly, detailed studies focussing on the link between small-scale turbulence and the different aspects of the life cycle of dinoflagellates will shed further light to understand the dynamics of this phytoplankton group in nature.

Acknowledgements. This work has been a joint effort of the Spanish projects TURFI (REN2002-01591/MAR), TURDITOX (CTM2005-03547/MAR), TURECOTOX (CTM2006-13884C02-00/MAR) and VARITEC (CTM2004-04442-C02) and by the EU project SEED (GOCE-CT-2005-003875). L. Bolli held a "Leonardo da Vinci" grant within the StudEX program of Switzerland and G. Llaveria an FPU fellowship from the Spanish Ministry of Science and Education (SMSE). Ò. Guadayol had a CSIC I3P doctoral contract. E. Berdalet and F. Peters were "Ramon y Cajal" scientists (SMSE), and K. van Lenning had a contract from the CRA (Centre de Referència en Aqüicultura, CIRIT-Generalitat de Catalunya, Spain).

Edited by: E. Boss

\section{References}

Anderson, D. M. and Lindquist, N. L.: Time-course measurements of phosphorus depletion and cyst formation in the dinoflagellate Gonyaulax tamarensis (Lebour), J. exp. mar. Biol. Ecol., 86, 113, 1985.

Berdalet, E.: Effects of turbulence on the marine dinoflagellate Gymnodinium nelsonii, J. Phycol., 28, 267-272, 1992.

Berdalet, E. and Estrada, M.: Effects of turbulence on several phytoplankton species, in: Toxic Phytoplankton Blooms in the Sea. Developments in Marine Biology, 5th International Conference on Toxic Marine Phytoplankton, Rhode Island USA, edited by: Shimizu, T. S. Y., 1993. 
Berdalet, E. and Estrada, M.: Effects of small-scale turbulence on the physiological functioning of marine algae, in: Algal Cultures, Analogues and Applications, edited by: Subba Rao, D. V., Enfield, NH, USA, Science Publishers, Inc., 2005.

Berdalet, E., Peters, F., Koumandou, L., Roldán, C., Guadayol, Ò., and Estrada, M.: Species-specific physiological response of dinoflagellates to quantified small-scale turbulence, J. Phycol., 43, in press, 2007.

Berman, T. and Shteiman, B.: Phytoplankton development and turbulent mixing in Lake Kinneret (1992-1996), J. Plankton Res., 20, 709-726, 1998.

Delgado, M., Estrada, M., Camp, J., Fernández, J. V., Santmartí, M., and Lletí, C.: Development of a toxic Alexandrium minutum Halim (Dinophyceae) bloom in the harbour of Sant Carles de la Ràpita (Ebro Delta, northwestern Mediterranean), Sci. Mar., 54, $1-7,1990$.

Dolan, J. R., Sall, N., Metcalfe, A., and Gasser, B.: Effects of turbulence on the feeding and growth of a marine oligotrich ciliate, Aquat. Microb. Ecol., 31, 183-192, 2003.

Estrada, M. and Blasco, D.: Two phases of the phytoplankton community in the Baja California upwelling, Limnol. Oceanogr., 24, 1065-1080, 1979.

Figueroa, R. I., Garcés, E., and Bravo, I.: Comparative study of the life cycles of Alexandrium tamutum and Alexandrium minutum (Gonyaulacales, Dinophyceae) in culture, J. Phycol., 43, in press, 2007.

Fritz, L. and Triemer, R. E.: A rapid simple technique utilizing Calcofluor White M2R for the visualization of dinoflagellate thecal plates, J. Phycol., 21, 662-664, 1985.

Garcés, E., Zingone, A., Montresor, M., Reguera, B. and Dale, B.: Life history of microalgal species causing harmful blooms, Research in Enclosed Seas, European Commission, Brussels, 189 pp, 2002.

Granata, T. C. and Dickey, T. D.: The fluid mechanics of copepod feeding in a turbulent flow: A theoretical approach, Prog. Oceanogr., 26, 243-261, 1991.

Guadayol, Ò. and Peters, F.: Analysis of wind events in a coastal area: a tool for assessing turbulence variability for studies on plankton, Sci. Mar., 70, 9-20, 2006.

Guillard, R. R. L.: Division rates, in: Handbook of Phycological Methods. I. Culture Methods and Growth Measurements, edited by: Stein, J. R., Cambridge, Cambridge University Press, 1973.

Guillard, R. R. L.: Culture of phytoplankton for feeding marine invertebrates, in: Culture of marine invertebrates, edited by: Smith, W. and Chanley, M. H., New York, N. Y., Plenum Publishing Corp., 1975.

Halim, Y.: Alexandrium minutum nov. g. nov. sp. dinoflagellé provocant des "eaux rouges", Vie et Milieu, 11, 102-105, 1960.

Hallegraef, G. M., Marshall, J. A., Valentine, J., and Hardiman, S.: Short cyst-dormancy period of an Australian isolate of the toxic dinoflagellate Alexandrium catenella, Mar. Freshwater Res., 49, 415-420, 1998.

Havskum, H.: Effects of small-scale turbulence on interactions between the heterotrophic dinoflagellate Oxyrrhis marina and its prey, Isochrysis sp. Ophelia, 57, 125-135, 2003.

Havskum, H. and Hansen, P. J.: Net growth of the bloom-forming dinoflagellate Heterocapsa triquetra and $\mathrm{pH}$ : why turbulence matters, Aquat. Microb. Ecol., 42, 55-62, 2006.

Havskum, H., Jansen, P. J., and Berdalet, E.: Effect of turbulence on sedimentation and net population growth of the dinoflagellate Ceratium tripos and interactions with its predator, Fragilidium subglobosum, Limnol. Oceanogr., 50, 1543-1551, 2005.

Honsell, G., Poletti, R., Pompei, M., Sidari, L., Milandri, A., Casadei, C., and Viviani, R.: Alexandrium minutum Halim and PSP contamination in the northern Adriatic Sea (Mediterranean Sea), in: Harmful and toxic algal blooms, edited by: Yasumoto, T., Oshima, Y., and Fukuyo, Y., Intergovernmental Oceanographic Institution, UNESCO, 1995.

Juhl, A. R., Trainer, V. L., and Latz, M. I.: Effect of fluid shear and irradiance on population growth and cellular toxin content of the dinoflagellate Alexandrium fundyense, Limnol. Oceanogr., 46, 758-764, 2001

Latasa, M., Van Lenning, K., Garrido, J. L., Scharek, R., Estrada, M., Rodríguez F., and Zapata M.: Losses of chlorophylls and carotenoids in aqueous acetone and methanol extracts prepared for RPHPLC analysis of pigments, Chromatographia, 53, 385391, 2001.

Kiørboe, T. and Saiz, E.: Planktivorous feeding in calm and turbulent environments, with emphasis on copepods, Mar. Ecol. Prog. Ser., 122, 135-145, 1995.

MacKenzie, B. R. and Leggett, W. C.: Wind-based models for estimating the dissipation rates of turbulent energy in aquatic environments: empirical comparisons, Mar. Ecol. Prog. Ser., 94, 207-216, 1993.

Margalef, R., Estrada, M., and Blasco, D.: Functional morphology of organisms involved in red tides, as adapted to decaying turbulence, in: Toxic Dinoflagellate Blooms, edited by: Taylor, D. L. and Seliger, H. H., Elsevier North Holland Inc., 1979.

Motulsky, H. J.: Prism 4 Statistics Guide -Statistical analyses for laboratory and clinical researchers., GraphPad Software, Inc., San Diego, USA., 150 pp, 2003.

Oshima, Y.: Post-column derivatization HPLC methods for paralytic shelfish poisons, in: Manual on harmful marine microalgae, edited by: Hallegraef, G. M., Anderson, D. M., and Cembella, A. D., 33, 81-94, IOC-UNESCO, 1995.

Peters, F. and Gross, T.: Increased grazing rates of microplankton in response to small-scale turbulence, Mar. Ecol. Prog. Ser., 115, 299-307, 1994.

Peters, F. and Redondo, J. M.: Turbulence generation and measurement: application to studies on plankton, in: Lectures on plankton and turbulence, edited by: Marrasé, C., Saiz, E., and Redondo, J. M., Sci. Mar., 61, suppl. 1, 205-228, 1997.

Peters, F. and Marrasé, C.: Effects of turbulence on plankton: an overview of experimental evidence and some theoretical considerations, Mar. Ecol. Prog. Ser., 205, 291-306, 2000.

Petersen, J. E., Sanford, L. P., and Kemp, W. M.: Coastal plankton responses to turbulent mixing in experimental ecosystems, Mar. Ecol. Prog. Ser., 171, 23-41, 1998.

Pollingher, U. and Zemel, E.: In situ and experimental evidence of the influence of turbulence on cell division processes of Peridinium cinctum forma westii (Lemm.) Lefèvre, Br. Phycol. J., 16, 281-287, 1981.

Smayda, T. J. and Reynolds, C. S.: Community assembly in marine phytoplankton: application of recent models to harmful algal blooms., J. Plankton Res., 23, 447-461, 2001.

Smith, B. C. and Persson, A.: Dinoflagellate cyst production in oneliter containers, J. Applied Phycol., 16, 401-405, 2004.

Smith, B. C. and Persson, A.: Synchronization of encystment of 
Scrippsiella lachrymosa (Dinophyta), J. Applied Phycol., 17, 317-321, 2005.

Stiansen, J. E. and Sundby, S.: Improved methods for generating and estimating turbulence in tanks suitable for fish larvae experiments, Sci. Mar., 65, 151-167, 2001.

Sullivan, J. M. and Swift, E.: Effects of small-scale turbulence on net growth rate and size of ten species of marine dinoflagellates, J. Phycol., 39, 83-94, 2003.

Sullivan, J. M., Swift, E., Donaghay, P. L., and Rines, J. E. B.: Small-scale turbulence affects the division rate and morphology of two red-tide dinoflagellates, Harmful Algae, 2, 183-199, 2003.

Thomas, W. H., Tynan, C. T., and Gibson, C. H.: Turbulencephytoplankton interrelationships, in: Progress Phycological Research, edited by: Round, F. E. and Chapman, D. J., Biopress Ltd., Chp. 5, 283-324, 1997.

Tynan, C. T.: The effects of small scale turbulence on dinoflagellates, Ph. D. Dissertation, University of California at San Diego, Scripps Institution of Oceanography, San Diego, California, USA, 227 pp, 1993.
Utermöhl, H.: Zur Vervollkommnung der quantitativen Phytoplankton-Methodik, Mitt. Int. Ver. Limnol., 9, 1-38, 1958.

Vila, M., Camp, J., Garcés, E., Masó, M., and Delgado, M.: High resolution spatio-temporal detection of potentially harmful dinoflagellates in confined waters of the NW Mediterranean, J. Plankton Res., 23, 497-514, 2001 a.

Vila, M., Garcés, E., Masó, M., and Camp, J.: Is the distribution of the toxic dinoflagellate Alexandrium catenella expanding along the NW Mediterranean coast?, Mar. Ecol. Prog. Ser., 222, 73-83, $2001 b$.

Wyatt, T. and Horwood, J.: Model which generates red tides, Nature, 244, 238-240, 1973.

Wyatt, T. and Jenkinson, I. R.: Notes on Alexandrium population dynamics, J. Plankton Res., 19, 551-575, 1997.

Yeung, P. K. K. and Wong, J. T. Y.: Inhibition of cell proliferation by mechanical agitation involves transient cell cycle arrest at G1 phase in dinoflagellates, Protoplasma, 173-178, 2003.

Yoshimadzu, S.: Sexual reproduction of Protogonyaulax catenella in culture, 2. Determination of mating type, Bull. Plankton Soc. Jap., 31, 107-111, 1984. 